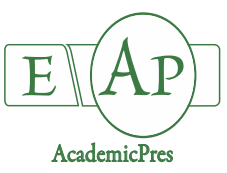

Kakabouki I et al. $(2020)$
Notulae Botanicae Horti Agrobotanici Cluj-Napoca 48(2):799-813
DOI: $10.15835 /$ nbha48211880
Research Article

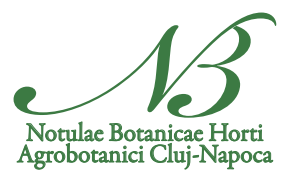

\title{
Fertilization expression via nitrogen indices in soybean crop under two system tillage
}

\author{
Ioanna KAKABOUKI*, Antigolena FOLINA, Charikleia ZISI, \\ Stella KARYDOGIANNI
}

\author{
Agricultural University of Athens, Department of Crop Science, Iera Odos 75, Votanikos, 11855 Athens, Greece; folinanti@gmail.com; \\ xarikleiazisi@gmail.com; stella.karidogianni@hotmail.com (*correspondingauthor); i.kakabouki@gmail.com
}

\begin{abstract}
Soybean (Glycine $\max$ L.) constitutes a crop that is currently of interest both for its nutritional properties in humans and animals and for its contribution to soil nitrogen. It belongs to legumes, that means that it can take $\mathrm{N}_{2}$ and channel it to the soil, to be assimilable from plants. In addition, its high oil and protein content makes it important because of its nutritional properties. Moreover, soybean is a crop that has a major impact on nitrogen indicators. In this study, set up two same experiments in 2018-2019, in Western Greece. There were identified the effects of different fertilizer application (Control, N80, N100, N120), and different tillage (conventional tillage (CT), no tillage (NT)), on soil (organic matter, root density, no nodules/soil) and in agronomic (LAI, height, N\% in upper parts, Yield, N\% in seeds, $\mathrm{N}$ uptake in upper parts, $\mathrm{N}$ uptake in seed, $\mathrm{N}$ total uptake) characteristics. As well as in nitrogen indicators (nitrogen use efficiency, nitrogen harvest index, nitrogen agronomic efficiency, effects of absorption, effects of uptake). Soil properties were affected mainly by the tillage. However agronomic characteristics presented more differences between the different fertilizer application and finally the indicators were affected on both the parameters.
\end{abstract}

Keywords: fertilization; nitrogen indicators; nitrogen uptake; soil tillage; soybean

\section{Introduction}

Soybean (Glycine $\max$ (L.) Merr.) cultivation is gaining ground over the years because it is a versatile crop that is mostly used as animal feed and secondarily in human nutrition (Souza, 2016). This is mainly due to its high adaptation to various conditions, for example on low-N soils (Keyser, 1992) and the high concentration of protein in seed and stems, over $40 \%$ (Mere, 2013). The oil and protein content are high so soya bean plants constitute high-quality feed (fish and animals), food and good raw material for biofuels (Hellal et al., 2013). Soybean cultivation in Greece began in the 80 's and a high percentage of oil were recorded. To date, it is mainly used for animal feed (Skoulou et al., 2011).

The utilization of applied nitrogen in the crop is related to the $\mathrm{N}_{2}$ fixation of soybean inasmuch the already available nitrogen in the soil is a factor that affects the amount of fixed-N (Keyser, 1992). The ability of soybean to biological nitrogen fixation is a key factor in the utilization of inorganic fertilization. Soybean plant can 
biologically fix 44 to $130 \mathrm{~kg} \mathrm{~N} \mathrm{ha}^{-1}$ per year (Sanginga et al., 2003) and for the high accumulation of $\mathrm{N}$ in the seed. requires a large amount of nitrogen (Hao et al., 2011). However, many researchers that $\mathrm{N}_{2}$ fixation is not enough for the needs of crop and fertilization take place (Wesley et al., 1998; Salvagiotti et al., 2008). On the other hand, adding $\mathrm{N}$ fertilizer is not clear if increase yields (Osborne et al., 2008). According to studies, applied $\mathrm{N}$ range from $50 \mathrm{~kg} \mathrm{~N}^{-1}{ }^{-1}$ to $200 \mathrm{~kg} \mathrm{~N}^{-1}{ }^{-1}$ (Salvagiotti et al., 2008). Salvagiotti et al. (2008) note the rising of the yields with the addition of a large amount of fertilizer ( $>4.5 \mathrm{mg}$ ha- 1 ) and a negative relationship with $\mathrm{N}_{2}$ fixation when the application is done very superficially. Another cost-effective approach to applied $\mathrm{N}$ is its split application where a rate provided during the growing season (Mirshekari, 2013).

Existing nitrogen in soil comes from either inorganic or organic fertilization. These two types of fertilizers are widely used to increase yields and protein in seed. Regarding inorganic fertilization, it has been noted that it caused a decrease in the nutritional quality of legumes (Bairwa et al., 2009). However, adding organic fertilizers can improve the efficiency of inorganic fertilizers (Mere et al., 2013). Another factor that offers better utilization of applied nitrogen is the cultivation systems based on legume crops that have the ability to regulate the nitrogen cycle (Crookston et al., 1991; Schipanski et al., 2010). In these systems, the availability of inorganic fertilizers may be limited due to the enrichment of the soil by $\mathrm{N}_{2}$ fixation (Vitousek et al., 2002). The combination of the above two factors can promote the sustainable use and utilization of mineral nitrogen. As data on Greek conditions is limited, it is necessary to investigate the balance of $\mathrm{N}$ from mineral and biological fixation to conserve natural resources and reduce nitration.

However, the biological nitrogen fixation of soybeans starts from the degrees of colonization by soil rhizobia which are affected by the soil and the weather. (Goss et al., 2002) consequently, from agricultural practices applied to the soil such as tillage. Reducing soil disturbance, for example, improves the physical parameters of the soil, such as structure, and at the same time the biological parameters that affect the stabilization of nitrogen (Kihara et al., 2011). Soil biological parameters including the activity of microorganisms such as those of the root nodule bacteria due to the biological nitrogen fixation. The practice of no tillage contributes to the growth of root bacteria in soybean cultivation (Ferreira $e t$ al., 2000). Moreover, the applied nitrogen increased the formation of nodules (Seneviratne et al., 2000; Wang et al., 2009). In addition, nodules and applied $\mathrm{N}$ can work together if $\mathrm{N}$ application is done before planting where nodules have not yet formed. (Bergersen, 1958). The effect of applied $\mathrm{N}$ on the biological nitrogen fixation of soybean follows the soil structure as a priority (Schipanski et al., 2009).

The amount of nitrogen from biological nitrogen fixation is affected by a variety of factors that affect production and yield (Keyser, 1992). Whether soil tillage affects soybean yields is ambiguous, many researchers say it affects and increases yields (Elmore, 1990; Okoth et al., 2014) while others that it does not affect (Lueschen et al., 1993). Soil tillage can also affect nitrogen fixation. The effect of reduced tillage and conventional tillage on nitrogen fixation in grain legumes has been investigated in Kenya and it was noted that nitrogen fixation increased with reduced treatment (Kihara et al., 2011).

The most efficient use of nitrogen (NUE) directly determines the yield and protein content of soybeans. Hao et al. (2011) mentioned that the NUE could be improved by genetic improvement, offering higher yields and better quality of soy products. Attia et al. (2015) mention that intercropping of corn and soybean and the interaction with N rates significantly affected NUE. Contrariwise, if NUE is calculated as the removal of $\mathrm{N}$ grains, increasing the rate $\mathrm{N}$ the NUE decreases (Halvorson et al., 2006).

In recent years, fertilizers have been developed to maximize nitrogen utilization, such as adding inhibitors of urea. In this experiment, we tried to combine some classic practices that are already widely used by producers to maximize nitrogen utilization. Also, while it is widely reported in the literature that soybean plants fix large amounts of $\mathrm{N}$, there are few studies to evaluate this $\mathrm{N}$. That is, to finally see, for example, how many $\mathrm{N}$ uptake the ground part of the plant and seeds. 
The objective of this study was to compare the response of soybean crop with various $\mathrm{N}$ rate fertilizers and conventional tillage system when planted at 2 years. Also, through nitrogen indices the evaluation of nitrogen fertilization in terms of crop development was expressed. The original hypothesis (H0) was if the indicators could effectively express soybean fertilization in different tillage systems, in contrast (H1) was that they could not express effectively.

\section{Materials and Methods}

\section{Experimental design}

Two same experiments, with soya crop was established in Western Greece, in Agrinio (38 $35^{\prime} 18 \mathrm{~N}$, $21^{\circ} 25^{\prime} 40 \mathrm{E}$, with altitude $\left.53 \mathrm{~m}\right)$, in 2018 and 2019. The soil was a clay loam, with $\mathrm{pH}\left(1: 1 \mathrm{H}_{2} \mathrm{O}\right) 6.72$ and organic matter content $2.78 \%$. The sites were managed according to organic agriculture guidelines (EC 834/2007). The density of plants was 350 plants ha ${ }^{-1}$. A drip irrigation system was used to irrigate the crop. The meteorological data on the air temperature and the precipitation of the experimental space during the experimental periods are presented in Figure 1.

The experiment was created on an area of $960 \mathrm{~m}^{2}$, according the split plot design with three replicates, two main plots (conventional tillage (CT), moldboard plowing at $25 \mathrm{~cm}$, followed by one rotary hoeing at 10$15 \mathrm{~cm}$, and no tillage, direct sowing (NT)). In additions were four sub-plots (fertilization treatments: control, application with $80 \mathrm{~kg} \mathrm{~N} \mathrm{ha}^{-1}(\mathrm{~N} 80)$, application with $100 \mathrm{~kg} \mathrm{~N} \mathrm{ha}^{-1}(\mathrm{~N} 100)$ and application with $120 \mathrm{~kg} \mathrm{~N}$ ha $\left.{ }^{1}(\mathrm{~N} 120)\right)$. Each main plot was $160 \mathrm{~m}^{2}$.

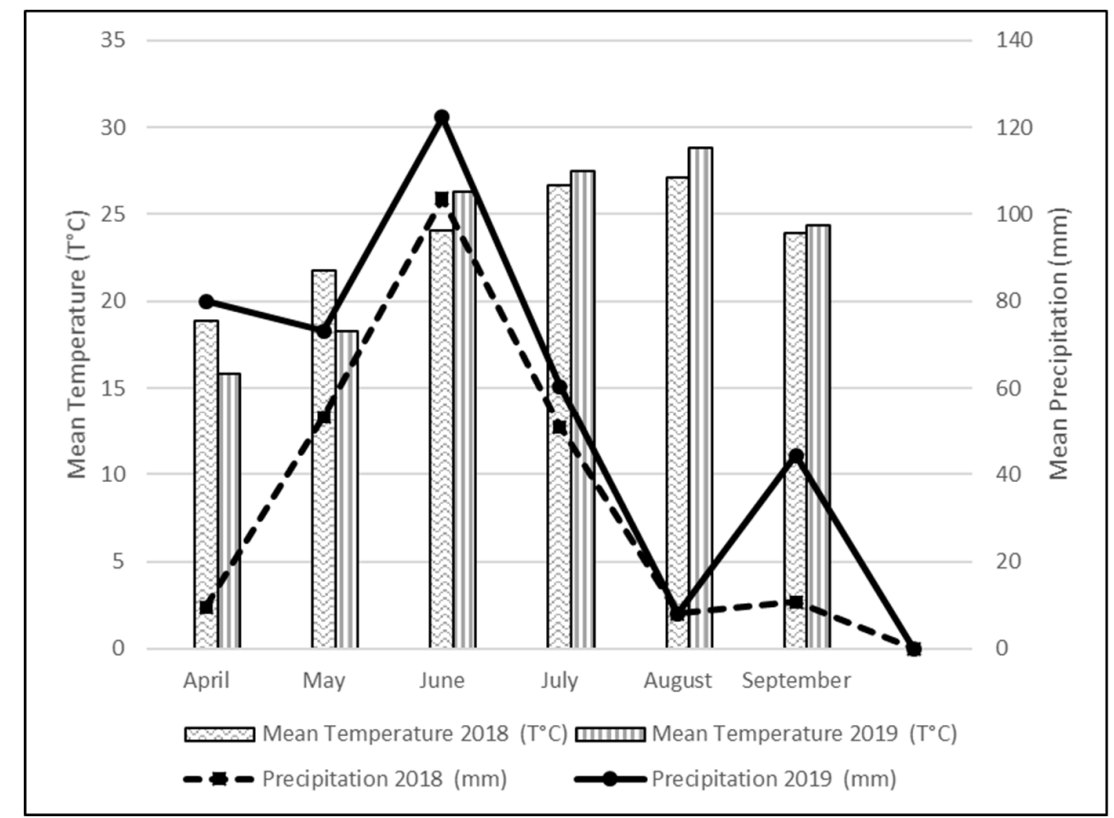

Figure 1. Meteorological data (mean monthly air temperature and precipitation) for experimental site during the experimental periods (April-September, 2018-2019)

\section{Measurements}

The total soil porosity was determined by $1-\mathrm{Db} / \mathrm{Dp}$, where $\mathrm{Dp}$ is the particle density $\left(2.5 \mathrm{~g} \mathrm{~cm}^{-3}\right)$ and $\mathrm{Db}$ is the soil density. The bulk soil density was determined for each plot by taking undisturbed soil cores with $100 \mathrm{~cm} 3$ taken from cylinders from a depth of $0-10 \mathrm{~cm}$. Three samples of $100 \mathrm{~cm} 3$ per plot were taken, in the flowering period. The undisturbed samples were finally dried in an oven at $100^{\circ} \mathrm{C}$ for 24 hours to obtain the 
dry mass of the soil and the soil density was calculated as follows: $\mathrm{Db}=\mathrm{dry}$ mass $(\mathrm{g}) / 100 \mathrm{~cm} 3$. Penetration resistance was calculated with penetrating DT. Organic matter was measured at the maturation stage, by Wakley black method (Wakley and Black, 1934).

Root specimens were collected in flowering and from the $0-25 \mathrm{~cm}$ layer using a cylindrical drill $(25 \mathrm{~cm}$ long, $10 \mathrm{~cm}$ in diameter) in the middle point between successive plants within a row. For each sample, roots were separated from soil after standing for $24 \mathrm{~h}$ in water $+(\mathrm{NaPO} 3) 6+\mathrm{Na} 2 \mathrm{CO} 3$. The dry root weight was then determined after drying one of the paired samples for 48 hours at $70^{\circ} \mathrm{C}$ (Kokko et al., 1993). To determine the density and diameter of the roots, the root samples were placed in a high-resolution scanner using DT software (Delta-T Scan version 2.04; Delta-T Devices Ltd, Burrwell, Cambridge, UK).

In addition, at the flowering was counted, the number of nodules at $100 \mathrm{~cm}^{3}$ soil. Other measurements at the flowering stage was the LAI, using SunScan (Delta-T Devices Ltd), and the plants' height $\mathrm{cm}$. Then, at the time of maturity was measured the number of pods per plant.

Moreover, the other measurements were taken on harvested products. There were weighted 1000 seeds from each experimental part. In dry matter upper measurement, leaves and stems $\left(\mathrm{kg} \mathrm{ka}^{-1}\right)$ were determined after drying for $72 \mathrm{~h}$ at $75^{\circ} \mathrm{C}$. As well there was counted the yield $\left(\mathrm{kg} \mathrm{ha}^{-1}\right)$, by manually harvesting the pods of the plants in moisture content $13 \%$. Nitrogen measurements were N\% in upper parts and $\mathrm{N}$ uptake in upper parts $\left(\mathrm{kg} \mathrm{ha}^{-1}\right), \mathrm{N} \%$ in seeds and $\mathrm{N}$ uptake in seeds $\left(\mathrm{kg} \mathrm{ha}^{-1}\right)$, and $\mathrm{N}$ total uptake $\left(\mathrm{kg} \mathrm{ha}^{-1}\right)$. The total nitrogen was determined by the Kjeldahl method (Bremner, 1960) using a Buchi 316 device. The samples were chosen randomly within each plot. All plant samples were ground to fine powder and used for determination of total nitrogen.

Nitrogen uptake and nitrogen uptake total were measured by the following equations (eq 1) and (eq 2) respectively.

$$
\begin{aligned}
& N \text {-uptake }=N \% \text { tissue }{ }^{*} \text { Dry matter yield upper parts } \\
& N \text {-uptake total }=N \text { yield upperparts }\left(\mathrm{kg} \mathrm{ha}^{-1}\right)+N \text { yield seed }\left(\mathrm{kg} \mathrm{ha}^{-1}\right)
\end{aligned}
$$

In addition, was calculated some nitrogen indicators. Nitrogen use efficiency were estimated by the equation 3.

$$
N U E=\left(N \text { total uptake }\left(\mathrm{kg} \mathrm{ha}^{-1}\right)-N \text { total uptake }\left(\mathrm{kg} \mathrm{ha}^{-1}\right)_{\text {control }}\right) / \mathrm{kg} \mathrm{N} \mathrm{ha}^{-1}
$$

Nitrogen Harvest Index is an indicator which is defined as a ratio of the concentration of $\mathrm{N}$ in seeds (seeds $\mathrm{N}$ uptake) to the total $\mathrm{N}$ in the plant (total plant $\mathrm{N}$ uptake) (eq 4). This indicator is positively related to seed yield.

$$
N H I=\text { seed } N \text { uptake }(\mathrm{kg}) / \text { total plan } N \text { uptake }(\mathrm{kg})
$$

Another Nitrogen indicator, is Nitrogen Agronomic Efficiency, which shows the amount of seed produced per $\mathrm{kg}$ of $\mathrm{N}$ fertilizer (eq 5).

$$
N A E=(\text { seed yield fertilizer-seed yield control) } / \mathrm{Nkg} \text { offertilizer }
$$

In this study, were calculated also the effects of absorption, which are defined the ration of nitrogen total uptake to quantity of $\mathrm{N}$ fertilizer (eq 6) and Effects of Uptake which are shown the ration of yield to nitrogen total uptake (eq 7).

$$
\begin{aligned}
& \text { Effects of Absorption }=N \text { total uptake }(\mathrm{kg} / \mathrm{ha}) / N \mathrm{Kg} \text { fertilizer }\left(\mathrm{kg} \mathrm{ha}^{-1}\right) \\
& \text { Effects of Uptake }=Y \text { ield }(\mathrm{kg} / \mathrm{ha}) / N \text { total uptake }\left(\mathrm{kg} \mathrm{ha}^{-1}\right)
\end{aligned}
$$




\section{Statistical analysis}

Analysis of variance was carried out on data using the Statistica (Stat Soft, 2011) logistic package as a completely randomized design. The analysis of variance (ANOVA) used a mixed model, with years and replications as random effects and tillage system and fertilization as fixed effects. Differences between means were separated using Tukey's test. Correlation analyses were used to describe the relationships between growth parameters and yield components using Pearson's correlation. All comparisons were made at the $5 \%$ level of significance $(\mathrm{p} \leq 0.05)$.

\section{Results}

In the Table 1, presented the soil characteristics as like as the total soil porosity. The values ranged from 39.6 to $41.3 \%$ in the first year in CT. Also, in NT the values were higher than CT ranged from 43 to $45 \%$. Correspondingly, in year B the values ranged from 39 to $41.7 \%$ in CT, and from 42.3 to $44.7 \%$ in NT. In the first and second year, and in the CT and NT, the control had not statistically significant difference with the N100 and the N80 had not statistically significant difference with the N120. In year 2018 in NT, the N100 had not statistically significant difference with the N120. The highest value was $44.7 \%$ in the N80, NT in second year (Table 1).

Table 1. The soil characteristics as effected by fertilizer treatments (control, inorganic fertilization $80 \mathrm{~kg}$ $\mathrm{N} \mathrm{ha}^{-1}$ (N80), inorganic fertilization $100 \mathrm{~kg} \mathrm{~N} \mathrm{ha}^{-1}(\mathrm{~N} 100)$ and inorganic fertilization $120 \mathrm{~kg} \mathrm{~N}^{-1}$ (N120)) and different tillage system (conventional and no tillage: CT and NT, respectively)

\begin{tabular}{|c|c|c|c|c|c|}
\hline Fertilization & $\begin{array}{l}\text { Total soil } \\
\text { porosity } \\
(\%)\end{array}$ & $\begin{array}{c}\text { Penetration } \\
\text { resistance } 0-30 \mathrm{~cm} \\
(\mathrm{MPa})\end{array}$ & $\begin{array}{l}\text { Organic } \\
\text { matter }\end{array}$ & 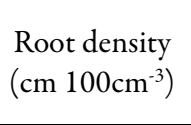 & $\begin{array}{c}\text { no nodules } \\
\left(100 \mathrm{~cm}^{-3} \text { soil }\right)\end{array}$ \\
\hline 2018 & \multicolumn{5}{|c|}{ CT } \\
\hline Control & $40.3^{a}$ & $2.627^{\mathrm{ns}}$ & $2.083^{\mathrm{a}}$ & $12.667^{\mathrm{a}}$ & $8.102^{\mathrm{a}}$ \\
\hline \begin{tabular}{|l|} 
N80 \\
\end{tabular} & $39.6^{\mathrm{b}}$ & $2.523^{\mathrm{ns}}$ & $2.250^{\mathrm{ac}}$ & $16.667^{\mathrm{b}}$ & $10.185^{\mathrm{ab}}$ \\
\hline N100 & $41^{a}$ & $2.570^{\mathrm{ns}}$ & $2.210^{\mathrm{b}}$ & $20.667^{\mathrm{c}}$ & $12.037^{\mathrm{b}}$ \\
\hline N120 & $41.3^{\mathrm{b}}$ & $2.630^{\mathrm{ns}}$ & $2.273^{c}$ & $23.333^{c}$ & $13.426^{c}$ \\
\hline 2018 & \multicolumn{5}{|c|}{ NT } \\
\hline Control & $43^{\mathrm{a}}$ & $1.963^{\mathrm{ns}}$ & $2.700^{\mathrm{a}}$ & $20^{a}$ & $10.648^{\mathrm{a}}$ \\
\hline N80 & $44.3^{b}$ & $1.977^{\mathrm{ns}}$ & $2.820^{\mathrm{ac}}$ & $24.667^{b}$ & $13.194^{\mathrm{ab}}$ \\
\hline N100 & $45^{c}$ & $1.860^{\mathrm{ns}}$ & $2.897^{\mathrm{b}}$ & $28.667^{c}$ & $15.278^{b}$ \\
\hline N120 & $45^{c}$ & $2.010^{\mathrm{ns}}$ & $2.817^{\mathrm{c}}$ & $32.667^{c}$ & $17.361^{\mathrm{c}}$ \\
\hline 2019 & \multicolumn{5}{|c|}{ CT } \\
\hline Control & $39^{a}$ & $2.627^{\mathrm{ns}}$ & $2.083^{\mathrm{a}}$ & $13^{\mathrm{a}}$ & $7.407^{\mathrm{a}}$ \\
\hline N80 & $39.7^{\mathrm{b}}$ & $2.547^{\mathrm{ns}}$ & $2.250^{\mathrm{ac}}$ & $17.667^{b}$ & $9.954^{\mathrm{ab}}$ \\
\hline N100 & $40.3^{a}$ & $2.550^{\mathrm{ns}}$ & $2.263^{\mathrm{b}}$ & $22.667^{\mathrm{c}}$ & $11.111^{\mathrm{b}}$ \\
\hline N120 & $41.7^{\mathrm{b}}$ & $2.550^{\mathrm{ns}}$ & $2.320^{c}$ & $26^{c}$ & $13.194^{\mathrm{c}}$ \\
\hline 2019 & \multicolumn{5}{|c|}{ NT } \\
\hline Control & $42.3^{a}$ & $1.977^{\mathrm{ns}}$ & $2.627^{\mathrm{a}}$ & $21.667^{\mathrm{a}}$ & $12.731^{\mathrm{a}}$ \\
\hline N80 & $44.7^{\mathrm{b}}$ & $2.083^{\text {ns }}$ & $2.767^{\mathrm{ac}}$ & $29.000^{\mathrm{b}}$ & $13.889^{\mathrm{ab}}$ \\
\hline N100 & $44.3^{a}$ & $2.020^{\mathrm{ns}}$ & $2.967^{\mathrm{b}}$ & $30.333^{c}$ & $16.204^{\mathrm{b}}$ \\
\hline N120 & $44^{\mathrm{b}}$ & $1.927^{\mathrm{ns}}$ & $3.117^{c}$ & $33.667^{\mathrm{c}}$ & $20.370^{c}$ \\
\hline$F_{\text {tillage }}$ & $74.726^{* *}$ & $301.619^{* * *}$ & $160.259^{* * *}$ & $83.566^{* * *}$ & $58.724^{* * *}$ \\
\hline$F_{\text {fertilization }}$ & 3.506 & $0.339^{n s}$ & $5.227^{* *}$ & $30.945^{* * *}$ & $23.489^{* * *}$ \\
\hline$F_{y e a r}$ & $1.142^{n s}$ & $0.188^{n s}$ & $0.763^{n s}$ & $3.888^{n s}$ & $1.072^{n s}$ \\
\hline
\end{tabular}




\begin{tabular}{|l|c|c|c|c|c|}
\hline$F_{\text {tillagex fertilization }}$ & $1.066^{n s}$ & $0.912^{n s}$ & $0.538^{n s}$ & $0.198^{n s}$ & $0.643^{n s}$ \\
\hline$F_{\text {tillagex year }}$ & $0.009^{n s}$ & $0.975^{n s}$ & $0.133^{n s}$ & $0.129^{n s}$ & $3.871^{n s}$ \\
\hline$F_{\text {fertilization } x \text { year }}$ & $0.336^{n s}$ & $1.04^{n s}$ & $0.985^{n s}$ & $0.134^{n s}$ & $0.3^{n s}$ \\
\hline$F_{\text {tillagex fertilization } x \text { year }}$ & $0.261^{n s}$ & $0.363^{n s}$ & $0.583^{n s}$ & $0.337^{n s}$ & $0.211^{n s}$ \\
\hline
\end{tabular}

In the penetration resistance $0-30 \mathrm{~cm}$ none value in the both years and in the different tillage had statistically significant difference between them. The highest value was $2.627 \mathrm{MPa}$ in control, in the first and second year in CT and the lowest was $1.860 \mathrm{MPa}$ in N100, in the first year in NT. The organic matter's values ranged from 2.083 to 2.273 in year 2018 in CT and from 2.083 to 2.320 in year 2019, respectively. In NT the values ranged from 2.817 to 2.820 in first year and from 2.627 to 3.117 in second year. It is emphasized that there were higher values in NT than CT, in both years. The N100 had statistically significant difference with the other treatments and the N80 had not statistically significant difference with the control, in CT and NT

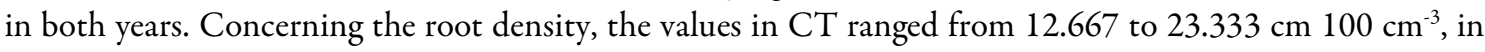

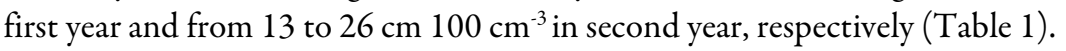

In the NT the values ranged from 20 to $32.667 \mathrm{~cm} 100 \mathrm{~cm}^{-3}$ in 2018 and from 21.667 to $33.667 \mathrm{~cm}$ $100 \mathrm{~cm}^{-3}, 2019$. The N100 had not statistically significant difference with the N120 and the N80 had statistically significant difference with the other fertilizers in both years in CT and NT. The highest value was

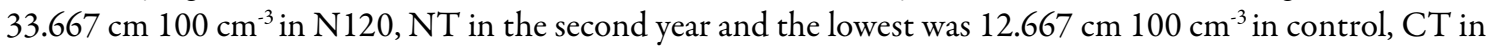
first year. Moreover, the values of nodules per $100 \mathrm{~cm}^{-3}$ soil in the NT in both years was higher than the CT. The control had not statistically significant difference with the N80 and the N80 had not statistically significant difference with the N100, in the first and second year, in CT and NT. The highest value was 20.370 $100 \mathrm{~cm}^{-3}$ soil, in N120, NT, the $7.407100 \mathrm{~cm}^{-3}$ soil was the lowest value in control, CT, in second year (Table 1). The LAI's values ranged from 4.623 to 5.340 in CT and from 4.920 to 5.907 in NT, in the first year. In the second year, in CT, ranged from 4.657 to 5.207 and from 5.027 to 5.880 in NT. All treatments had statistically significant difference between them, in both years and in the CT, NT (Table 2). Concerning the height, the highest value was $56 \mathrm{~cm}$ in N100, NT, in the second year. The $42 \mathrm{~cm}$ was the lowest value, in control, CT in the first year. In first and second year the values in NT was higher than CT. In year A and B, as in the CT and NT the treatments had statistically significant difference between them. Also, in number of pods plant ${ }^{-1}$, the values ranged from 37 to 47 plant $^{-1}$ in CT and from 40 to 51 plant $^{-1}$ in NT, in first year. Respectively, in the second year the values in CT ranged from 36 to 42 plant $^{-1}$ and from 39 to 50 plant $^{-1}$, in NT. The control had statistically significant difference with the other treatments. The $\mathrm{N} 80$ had not statistically significant difference with the N100, in both years and in CT, NT. In the 1000 seeds weight the highest value was $33 \mathrm{~g}$ in N120, in $\mathrm{NT}$, in year A and B. And the lowest was $28 \mathrm{~g}$ in control, in CT in year A. In both years and in NT the treatments had statistically significant difference between them (Table 2). In the second year in CT the N80 had not statistically significant difference with the N100. Moreover, in DM yield parts stover, the values ranged in first year from 3,747 to $4,195 \mathrm{~kg} \mathrm{ha}^{-1}$, in CT, and from 3,978 to $4,348 \mathrm{~kg} \mathrm{ha}^{-1}$ in NT. Also, in the second year in CT ranged from 3,700 to $4,148 \mathrm{~kg} \mathrm{ha}^{-1}$ and from 3,808 to $4,368 \mathrm{~kg} \mathrm{ha}^{-1}$. The highest value was $4,368 \mathrm{~kg} \mathrm{ha}^{-1}$ in N120, NT in the second year. In percentage N in upper parts, the control had not statistically significant difference with the N100. The N80 had statistically significant difference with the other treatments, in both years and in the CT, NT. Moreover, in yield the highest value was 4,570 $\mathrm{kg} \mathrm{ha}^{-1}$, in N120, NT, in first year and the lowest was 4,015 in control, CT in second year. The values ranged from 4,050 to $4,312 \mathrm{~kg} \mathrm{ha}^{-1}$ in CT and from 4,140 to 4,570 $\mathrm{kg} \mathrm{ha}^{-1}$ in NT in the first year. In the second year, in CT ranged from 4,015 to 4,373 $\mathrm{kg} \mathrm{ha}$ ${ }^{1}$ and in NT from 4,117 to 4,550 $\mathrm{kg} \mathrm{ha}^{-1}$. In percentage N in seeds, in the first year the N80 had not statistically significant difference with the N100. And the N100 had not statistically significant difference with the N120, in CT and NT. Furthermore, in second year, only the N100 had not statistically significant difference with the N120. The highest value was 7.350 in N100, NT in year B. The lowest value was 6.477 in control, CT in year A (Table 2). 
Table 2. The agronomic characteristics as effected by fertilizer treatments (control, inorganic fertilization $80 \mathrm{~kg} \mathrm{~N} \mathrm{ha}^{-1}$ (N80), inorganic fertilization $100 \mathrm{~kg} \mathrm{~N} \mathrm{ha}^{-1}(\mathrm{~N} 100)$ and inorganic fertilization $120 \mathrm{~kg} \mathrm{~N} \mathrm{ha}^{-1}$ (N120)) and different tillage system (conventional and no tillage: CT, and NT, respectively).

\begin{tabular}{|c|c|c|c|c|c|c|c|c|}
\hline Fertilization & LAI & $\begin{array}{l}\text { Plant } \\
\text { height } \\
(\mathrm{cm})\end{array}$ & $\begin{array}{l}\text { No pods } \\
\text { plant }^{-1}\end{array}$ & $\begin{array}{c}1000 \text { seeds } \\
\text { weight } \\
\text { (g) }\end{array}$ & $\begin{array}{l}\text { DM yield } \\
\text { upper parts } \\
\text { STOVER } \\
\mathrm{kg} \mathrm{ha}^{-1}\end{array}$ & $\begin{array}{c}\mathrm{N} \text { in } \\
\text { upper } \\
\text { parts } \\
(\%)\end{array}$ & $\begin{array}{c}\text { Yield } \\
\text { Kg ha }^{-1} \\
\text { Gw }\end{array}$ & $\begin{array}{c}\mathrm{N} \text { in seeds } \\
(\%)\end{array}$ \\
\hline 2018 & \multicolumn{8}{|c|}{ CT } \\
\hline Control & $4.623^{\mathrm{a}}$ & $42^{a}$ & $37^{a}$ & $28^{a}$ & $3,747^{a}$ & $1.700^{\mathrm{a}}$ & $4,050^{a}$ & $6.477^{\mathrm{a}}$ \\
\hline N80 & $4.923^{\mathrm{b}}$ & $45^{\mathrm{b}}$ & $41^{\mathrm{b}}$ & $29^{\mathrm{b}}$ & $3,923^{b}$ & $1.777^{\mathrm{b}}$ & $4,150^{b}$ & $6.840^{\mathrm{b}}$ \\
\hline N100 & $5.137^{c}$ & $47^{c}$ & $42^{\mathrm{bc}}$ & $30^{c}$ & $4,045^{c}$ & $1.827^{\mathrm{ac}}$ & $4,243^{c}$ & $6.923^{b c}$ \\
\hline N120 & $5.340^{\mathrm{d}}$ & $52^{\mathrm{d}}$ & $44^{c}$ & $31^{\mathrm{d}}$ & $4,195^{\mathrm{d}}$ & $1.860^{c}$ & $4,312^{\mathrm{d}}$ & $7.040^{c}$ \\
\hline 2018 & \multicolumn{8}{|c|}{ NT } \\
\hline Control & $4.920^{\mathrm{a}}$ & $44^{\mathrm{a}}$ & $40^{a}$ & $29^{a}$ & $3,978^{a}$ & $1.793^{\mathrm{a}}$ & $4,140^{\mathrm{a}}$ & $6.877^{\mathrm{a}}$ \\
\hline N80 & $5.220^{\mathrm{b}}$ & $47^{b}$ & $44^{\mathrm{b}}$ & $31^{\mathrm{b}}$ & $4,118^{b}$ & $1.873^{\mathrm{b}}$ & $4,300^{\mathrm{b}}$ & $7^{\mathrm{b}}$ \\
\hline N100 & $5.393^{c}$ & $52^{c}$ & $47^{\mathrm{bc}}$ & $32^{c}$ & $4,237^{c}$ & $1.987^{\mathrm{ac}}$ & $4,410^{c}$ & $7.127^{\mathrm{bc}}$ \\
\hline N120 & $5.907^{\mathrm{d}}$ & $54^{\mathrm{d}}$ & $51^{\mathrm{c}}$ & $33^{\mathrm{d}}$ & $4,348^{\mathrm{d}}$ & $2.117^{\mathrm{c}}$ & $4,570^{\mathrm{d}}$ & $7.247^{c}$ \\
\hline 2019 & \multicolumn{8}{|c|}{ CT } \\
\hline Control & $4.657^{\mathrm{a}}$ & $44^{\mathrm{a}}$ & $36^{a}$ & $29^{a}$ & $3,700^{a}$ & $1.753^{\mathrm{a}}$ & $4,015^{a}$ & $6.857^{\mathrm{a}}$ \\
\hline \begin{tabular}{|l|} 
N80 \\
\end{tabular} & $4.813^{b}$ & $47^{b}$ & $39^{\mathrm{b}}$ & $30^{\mathrm{b}}$ & $3,860^{\mathrm{b}}$ & $1.740^{\mathrm{b}}$ & $4,145^{b}$ & $6.950^{\mathrm{b}}$ \\
\hline N100 & $5.143^{c}$ & $51^{\mathrm{c}}$ & $41^{\mathrm{bc}}$ & $30^{\mathrm{b}}$ & $4,042^{c}$ & $1.783^{\mathrm{ac}}$ & $4,297^{c}$ & $7.150^{c}$ \\
\hline N120 & $5.207^{\mathrm{d}}$ & $53^{\mathrm{d}}$ & $42^{c}$ & $31^{\mathrm{c}}$ & $4,148^{\mathrm{d}}$ & $1.857^{\mathrm{c}}$ & $4,373^{d}$ & $7.230^{c}$ \\
\hline 2019 & \multicolumn{8}{|c|}{ NT } \\
\hline Control & $5.027^{\mathrm{a}}$ & $44^{a}$ & $39^{a}$ & $30^{\mathrm{a}}$ & $3,808^{a}$ & $1.803^{\mathrm{a}}$ & $4,117^{\mathrm{a}}$ & $6.960^{\mathrm{a}}$ \\
\hline N80 & $5.220^{\mathrm{b}}$ & $50^{\mathrm{b}}$ & $42^{\mathrm{b}}$ & $31^{\mathrm{b}}$ & $4,063^{b}$ & $1.817^{\mathrm{b}}$ & $4,270^{\mathrm{b}}$ & $7.213^{\mathrm{b}}$ \\
\hline N100 & $5.517^{\mathrm{c}}$ & $54^{c}$ & $46^{\mathrm{bc}}$ & $32^{c}$ & $4,228^{c}$ & $1.940^{\mathrm{ac}}$ & $4,390^{c}$ & $7.350^{c}$ \\
\hline N120 & $5.880^{d}$ & $56^{d}$ & $50^{c}$ & $33^{d}$ & $4,368^{\mathrm{d}}$ & $1.974^{c}$ & $4,550^{\mathrm{d}}$ & $7.387^{c}$ \\
\hline$F_{\text {tillage }}$ & $51.161^{* * *}$ & $19.022^{* * *}$ & $31.439^{* * *}$ & $78.899^{* * *}$ & $64.22^{* * *}$ & $11.284^{* *}$ & $46.956^{* *}$ & $76.896^{* *}$ \\
\hline$F_{\text {fertilization }}$ & $34.755^{* * *}$ & $61.179^{* * *}$ & $19.465^{* * *}$ & $46.726^{* *}$ & $71.503^{* * *}$ & $5.108^{* *}$ & $56.346^{* * *}$ & $61.117^{* * *}$ \\
\hline$F_{\text {year }}$ & $5.91 E-12^{n s}$ & $13.12^{* * *}$ & $2.897^{n s}$ & $5.545^{*}$ & $4.026^{n s}$ & $0.787^{n s}$ & $0.012^{n s}$ & $65.822^{* * *}$ \\
\hline$F_{\text {tillagex fertilization }}$ & $1.619^{n s}$ & $1.2^{n s}$ & $1.49^{n s}$ & $0.265^{n s}$ & $0.067^{n s}$ & $0.55^{n s}$ & $1.476^{n s}$ & $0.372^{n s}$ \\
\hline$F_{\text {tillage xyear }}$ & $0.806^{n s}$ & $0.268^{n s}$ & $0.040^{n s}$ & $0.125^{n s}$ & $0.081^{n s}$ & $0.472^{n s}$ & $0.986^{n s}$ & $1.632^{n s}$ \\
\hline$F_{\text {fertilization x year }}$ & $0.482^{n s}$ & $0.632^{n s}$ & $0.057^{n s}$ & $0.585^{n s}$ & $1.039^{n s}$ & $0.363^{n s}$ & $0.343^{n s}$ & $0.608^{n s}$ \\
\hline $\begin{array}{l}F_{\text {tillage } x \text { fertilization }} \\
\text { year }\end{array}$ & $0.007^{n s}$ & $0.894^{n s}$ & $0.007^{n s}$ & $0.075^{n s}$ & $0.735^{n s}$ & $0.164^{n s}$ & $0.266^{n s}$ & $3.075^{n s}$ \\
\hline
\end{tabular}

Concerning the $\mathrm{N}$ uptake in upper parts, in the first year, the values ranged from 64 to $78 \mathrm{~kg} \mathrm{ha}^{-1}$, in CT and from 71 to $92 \mathrm{~kg} \mathrm{ha}^{-1}$ in NT. In the second year, in CT ranged from 65 to $77 \mathrm{~kg} \mathrm{ha}^{-1}$ and from 69 to $86 \mathrm{~kg}$ $\mathrm{ha}^{-1}$ in NT (Table 3). The N80 had not statistically significant difference with the control, and the N100 had not statistically significant difference with the N80 and with the N120, in both years and in the CT, NT. In N uptake in seed, all treatments had statistically significant difference between them in year A and B and in the CT, NT. The highest value was $336 \mathrm{~kg} \mathrm{ha}^{-1}$ in N120, NT in second year. Also, the lowest value was $262 \mathrm{~kg} \mathrm{ha}^{-1}$ in control, CT in the first year. 
Table 3. The nitrogen indicators as effected by fertilizer treatments (control, inorganic fertilization $80 \mathrm{~kg}$ $\mathrm{N} \mathrm{ha}^{-1}$ (N80), inorganic fertilization $100 \mathrm{~kg} \mathrm{~N} \mathrm{ha}^{-1}(\mathrm{~N} 100)$ and inorganic fertilization $120 \mathrm{~kg} \mathrm{~N} \mathrm{ha}^{-1}$ (N120)) and different tillage system (conventional and no tillage: CT and NT, respectively)

\begin{tabular}{|c|c|c|c|c|c|c|c|c|}
\hline Fertilization & $\begin{array}{c}\mathrm{N} \text { uptake } \\
\text { in upper } \\
\text { parts } \\
\mathrm{kg} \mathrm{ha}^{-1}\end{array}$ & $\begin{array}{c}\mathrm{N} \text { uptake } \\
\text { in SEED } \\
\mathrm{kg} \mathrm{ha}^{-1}\end{array}$ & $\begin{array}{l}\text { Nt total } \\
\text { uptake } \\
\mathrm{kg} \mathrm{ha}^{-1}\end{array}$ & NUE & NHI & NAE & $\begin{array}{c}\text { Eff of } \\
\text { absorption } \\
\mathrm{Nt} \mathrm{Ns}^{-1}\end{array}$ & $\begin{array}{c}\text { Eff of } \\
\text { uptake Gw } \\
\mathrm{Nt}^{-1}\end{array}$ \\
\hline 2018 & \multicolumn{8}{|c|}{ CT } \\
\hline Control & $64^{a}$ & $262^{a}$ & $326^{a}$ & - & $0.805^{\mathrm{a}}$ & - & - & $12.429^{\mathrm{a}}$ \\
\hline N80 & $70^{\mathrm{ab}}$ & $284^{\mathrm{b}}$ & $354^{\mathrm{b}}$ & $0.269^{a}$ & $0.803^{\mathrm{b}}$ & $1.25^{\mathrm{a}}$ & $4.420^{\mathrm{a}}$ & $11.739^{\mathrm{b}}$ \\
\hline N100 & $74^{\mathrm{bc}}$ & $294^{c}$ & $368^{c}$ & $0.181^{\mathrm{ab}}$ & $0.799^{a}$ & $1.933^{\mathrm{b}}$ & $3.677^{\mathrm{b}}$ & $11.543^{c}$ \\
\hline N120 & $78^{\mathrm{c}}$ & $304^{\mathrm{d}}$ & $382^{\mathrm{d}}$ & $0.177^{\mathrm{b}}$ & $0.796^{\mathrm{b}}$ & $2.181^{\mathrm{c}}$ & $3.180^{c}$ & $11.306^{\mathrm{c}}$ \\
\hline 2018 & \multicolumn{8}{|c|}{ NT } \\
\hline Control & $71^{a}$ & $285^{a}$ & $356^{a}$ & - & $0.800^{a}$ & - & - & $11.631^{\mathrm{a}}$ \\
\hline N80 & $77^{\mathrm{ab}}$ & $301^{\mathrm{b}}$ & $378^{\mathrm{b}}$ & $0.203^{\mathrm{a}}$ & $0.796^{\mathrm{b}}$ & $2^{\mathrm{a}}$ & $4.727^{a}$ & $11.376^{\mathrm{b}}$ \\
\hline N100 & $84^{\mathrm{bc}}$ & $314^{\mathrm{c}}$ & $399^{\circ}$ & $0.133^{\mathrm{ab}}$ & $0.789^{\mathrm{a}}$ & $2.7^{b}$ & $3.985^{b}$ & $11.077^{c}$ \\
\hline N120 & $92^{c}$ & $331^{d}$ & $423^{d}$ & $0.140^{\mathrm{b}}$ & $0.783^{\mathrm{b}}$ & $3.583^{c}$ & $3.527^{\mathrm{c}}$ & $10.807^{c}$ \\
\hline 2019 & \multicolumn{8}{|c|}{$\mathbf{C T}$} \\
\hline Control & $65^{a}$ & $275^{\mathrm{a}}$ & $340^{a}$ & - & $0.809^{\mathrm{a}}$ & - & - & $11.803^{\mathrm{a}}$ \\
\hline N80 & $67^{\mathrm{ab}}$ & $288^{\mathrm{b}}$ & $355^{b}$ & $0.159^{a}$ & $0.811^{\mathrm{b}}$ & $1.625^{\mathrm{a}}$ & $4.441^{a}$ & $11.670^{\mathrm{b}}$ \\
\hline N100 & $72^{\mathrm{bc}}$ & $307^{\mathrm{c}}$ & $379^{c}$ & $0.191^{\mathrm{ab}}$ & $0.810^{\mathrm{a}}$ & $2.817^{\mathrm{b}}$ & $3.793^{b}$ & $11.329^{c}$ \\
\hline N120 & $77^{\mathrm{c}}$ & $316^{\mathrm{d}}$ & $393^{d}$ & $0.074^{\mathrm{b}}$ & $0.804^{\mathrm{b}}$ & $2.986^{\mathrm{c}}$ & $3.277^{\mathrm{c}}$ & $11.123^{c}$ \\
\hline 2019 & \multicolumn{8}{|c|}{ NT } \\
\hline Control & $69^{a}$ & $287^{a}$ & $355^{a}$ & - & $0.807^{\mathrm{a}}$ & - & - & $11.591^{\mathrm{a}}$ \\
\hline N80 & $74^{\mathrm{ab}}$ & $308^{\mathrm{b}}$ & $382^{\mathrm{b}}$ & $0.268^{\mathrm{a}}$ & $0.807^{\mathrm{a}}$ & $1.917^{\mathrm{a}}$ & $4.772^{\mathrm{a}}$ & $11.184^{\mathrm{b}}$ \\
\hline N100 & $82^{\mathrm{bc}}$ & $323^{c}$ & $405^{c}$ & $0.146^{\mathrm{ab}}$ & $0.797^{\mathrm{b}}$ & $2.733^{\mathrm{b}}$ & $4.047^{b}$ & $10.849^{c}$ \\
\hline N120 & $86^{c}$ & $336^{\mathrm{d}}$ & $422^{\mathrm{d}}$ & $0.112^{\mathrm{b}}$ & $0.796^{\mathrm{b}}$ & $3.611^{\mathrm{c}}$ & $3.519^{c}$ & $10.779^{c}$ \\
\hline$F_{\text {tillage }}$ & $26.923^{* * *}$ & $99.4^{* * *}$ & $68.75^{* * *}$ & $0.075^{\mathrm{ns}}$ & $8.278^{* *}$ & $11.902^{* *}$ & $51.476^{* *}$ & $64.695^{* * *}$ \\
\hline$F_{\text {fertilization }}$ & $18.14^{* * *}$ & $98.402^{* * *}$ & $60.733^{* * *}$ & $17.278^{* * *}$ & $3.262^{*}$ & $98.562^{* * *}$ & $4264.672^{* * *}$ & $43.602^{* * *}$ \\
\hline$F_{\text {year }}$ & $1.916^{\mathrm{ns}}$ & $17.837^{* *}$ & $3.045^{*}$ & $0.702^{\mathrm{ns}}$ & $10.714^{*}$ & $3.523^{\mathrm{ns}}$ & $1.77^{\mathrm{ns}}$ & $12.125^{* * *}$ \\
\hline$F_{\text {tillagex fertilization }}$ & $0.66^{\mathrm{ns}}$ & $0.63^{\text {ns }}$ & $0.658^{\mathrm{ns}}$ & $0.389^{\mathrm{ns}}$ & $0.485^{\text {ns }}$ & $2.415^{\mathrm{ns}}$ & $5.784^{* *}$ & $0.126^{\mathrm{ns}}$ \\
\hline$F_{\text {tillage } x \text { year }}$ & $0.545^{\mathrm{ns}}$ & $1.893^{\text {ns }}$ & $1.335^{\mathrm{ns}}$ & $1.896^{\mathrm{ns}}$ & $0.097^{\mathrm{ns}}$ & $3.678^{\text {ns }}$ & $0.289^{\text {ns }}$ & $1.783^{\text {ns }}$ \\
\hline$F_{\text {fertilization x year }}$ & $0.128^{\text {ns }}$ & $0.329^{\mathrm{ns}}$ & $0.15^{\mathrm{ns}}$ & $0.551^{\mathrm{ns}}$ & $0.157^{\text {ns }}$ & $0.651^{\mathrm{ns}}$ & $0.345^{\text {ns }}$ & $0.827^{\text {ns }}$ \\
\hline$F_{\text {tillage } x \text { fertilization } x \text { year }}$ & $0.108^{\text {ns }}$ & $0.595^{\mathrm{ns}}$ & $0.325^{\mathrm{ns}}$ & $0.806^{\mathrm{ns}}$ & $0.086^{\mathrm{ns}}$ & $0.507^{\mathrm{ns}}$ & $0.215^{\text {ns }}$ & $1.882^{\mathrm{ns}}$ \\
\hline
\end{tabular}

\section{Discussion}

It is well known, that tillage is a method that causes fine-grain soil. In addition, the smaller the soil grains, the lower its porosity. So, on the treatment of no tillage the porosity will be great unlike the soil after conventional tillage. In the present study, it was shown that the no tillage treatments increased the soil porosity rate by about $10 \%$. Porosity is negative correlated in the penetration register. Thus, the greater the porosity, the lower its penetration, because of the soil pores size. Our results shown that in no tillage treatment the penetration register was $27 \%$ lower compared with conventional tillage. As well Alvarez and Steinbach (2009) reported that under no tillage the cone penetration increased by $50 \%$. This fact affects the roots density, due to roots growth is correlative with the register, so if there are more roots on $100 \mathrm{~cm}$ soil, there are more nodules in the same soil area. Thus, the present experiments had an increase in the root density and the number of nodules almost $48 \%$ and $30 \%$ respectively. Soil leverage promotes the oxidation of organic matter that has risen 
to the surface of the soil due to its contact with $\mathrm{O}_{2}$, high atmospheric temperature and solar radiation this is how the organic matter in our study increased by about $27 \%$. There are references in the literature which showed that lower organic matter was found in conventional treatment (Bilalis et al., 2010).

In terms of fertilization applications, total soil porosity and penetration register, are not significantly affected by them. On the other hand, organic matter is positively associated with nitrogen application. This is due to the replacement of nitrogen in the soil. It is known that legumes for their development mainly use nitrogen that is injected into the soil by the process of nitrogen fixation and organic matter. Thus, by nitrogen application, soil exhaustion is reduced. In addition, the application of nitrogen is positively related to root density, and therefore to the number of nodules. Sidiras et al. (1999) reported that in vetch crop no tillage treatment have a positive effect on root weight. Furthermore, if there is not enough $\mathrm{N}$ available in the soil during the nodule growth, $\mathrm{N}$ levels in legumes are insufficient (Hardy and Havelka, 1975; Sprent, 1985; Streeter, 1988). This is why, unlike other studies (Ntambo et al., 2017), in this study was observed an increase in the number of nodules per $100 \mathrm{~cm}^{3}$.

Nitrogen $(\mathrm{N})$, is an important nutrient for soybean growth and development. In soybean cultivation the application of nitrogen helps the vegetative growth of the plant. The agronomic characteristics such as plant height, dry weight and crop yield are improving by the application but also by the amount of nitrogen in the crop. In general, the application of nitrogen in all crops results an increase in yields. According to a study that has been carried out, there is a need to supply inorganic nitrogen to soybeans for higher yields due to the fact that it cannot meet the high nitrogen needs through nitrogen fixation (Kumawat et al., 2000).

A study conducted by Saxena and Chandal (1992), showed that the maximum plant height was presented in $40 \mathrm{~N} \mathrm{~kg} \mathrm{ha}^{-1}$. Naik and Rao (2004), conducted an experiment in which they recorded the same result in terms of height increase. In our results the highest value in plant height was in N100 and in N120. It was observed that the plant height increased from control to N120. This is due to the fact, that nitrogen promotes plant growth in general, with the result that as the levels of applied nitrogen increase, so does the plant height, the same observed by Pradhan et al. (1995), in nitrogen levels from 0 to $80 \mathrm{~kg} \mathrm{ha}^{-1}$.

It was observed, that as the amount of nitrogen applied increased, so increased the LAI, where in NT values were higher than in CT in both years. Warner and Newton (2005), reported similar results in LAI, that is, an increase in the amount of nitrogen applied resulted an increase in LAI. The increase in nitrogen resulted in higher values for pods per plant as well as in yield. According to our results, the treatments with nitrogen fertilizers were had statistically significant difference with the control, in number for pods plant ${ }^{-1}$ and in the yield. As reported by, Jadhav et al. (2009) the number of pods plant ${ }^{-1}$ and 1000 seed weight of soybean were increased with a application of nitrogen fertilizer. Also, and the Gai et al. (2017), had recorded higher seed yields after the nitrogen application. 


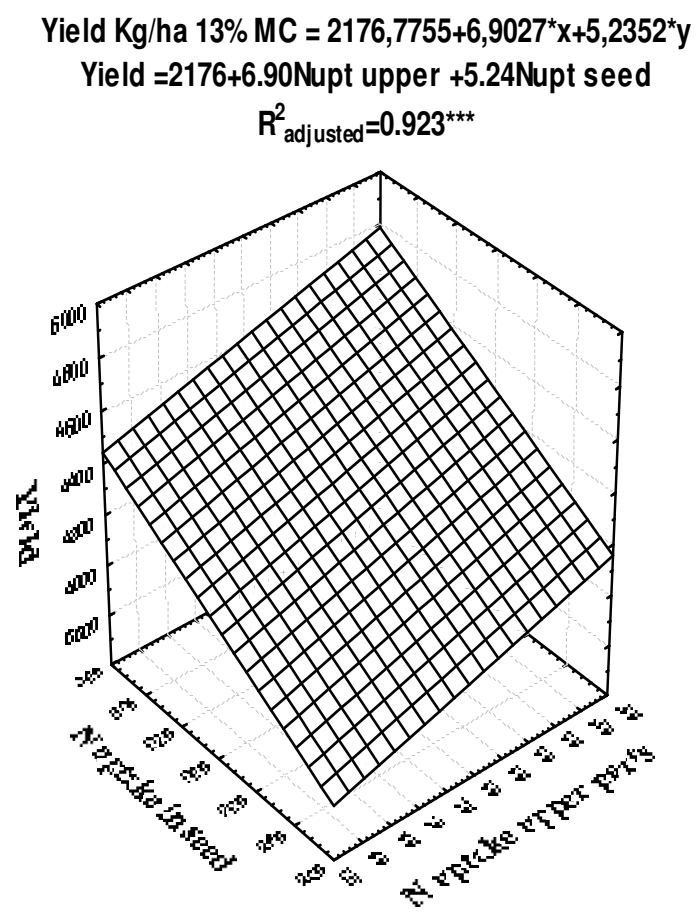

Figure 2. 3D-graph and linear equation between Yield and Nuptake in seeds \& $\mathrm{N}$ total uptake

The percentage of nitrogen in seed was higher with nitrogen fertilizers and more specifically the highest amounts of nitrogen had the highest percentages of nitrogen content. The control had the lowest value in the both years and in the both tillage systems. Kumawat et al. (2000), had reported that the protein content increased with an increase in the nitrogen levels. The results of our experiment regarding the content of nitrogen in the seed can be followed by this report due to the fact that the synthesis of proteins has as a necessary component nitrogen, so the high amounts of nitrogen therefore have a high protein content.

$\mathrm{N}$ uptake in upper parts $\mathrm{kg} \mathrm{ha}^{-1}$ was affected by tillage and fertilization. The $\mathrm{N}$ uptake in upper parts was increased with the rise of $\mathrm{N}$ and the undisturbed soil. It is noted that treatment of tillage gave lower values to $\mathrm{N}$ uptake in upper parts. This may be because undisturbed soil does not affect AM and soil microorganisms (Bilalis et al., 2012), so they act better and absorb more N. This is also confirmed by the positive correlation between Total soil porosity (\%) and $\mathrm{N}$ uptake in upper parts $(\mathrm{r}=0.5815, \mathrm{p}=0.001)$. This positive relationship is also noted with $\mathrm{N}$ uptake in seed $\left(\mathrm{r}=0.58^{\prime \prime \prime}\right)$ and with $\mathrm{N}$ total uptake $\left(\mathrm{r}=0.60^{\circ}\right)$.

$\mathrm{N}$ uptake in seed $\mathrm{kg} \mathrm{ha}^{-1}$ was affected by tillage, fertilization and year. In both years, in conventional tillage we had a lower difference between the maximum value (N120) and the control. So, we noticed that keeping the soil undisturbed helps the soybean to absorb more $\mathrm{N}$ in the seeds, therefore better seed quality. Additionally, keeping the soil undisturbed during these 2 years, it is noted that in the 2 nd year the $\mathrm{N}$ uptake in seed was higher. Also, the direct effect of $\mathrm{N}$ fertilizers on the increase of seed storage proteins mentioned by Martre et al. (2003).

$\mathrm{N}$ total uptake $\mathrm{kg} \mathrm{ha}^{-1}$ was affected by tillage $(\mathrm{p}=0.001)$, fertilization $(\mathrm{p}=0.001)$ and year $(\mathrm{p}=0.01)$. The total $\mathrm{N}$ uptake (above-ground and seed) was consistently above $350 \mathrm{~kg} \mathrm{~N} \mathrm{ha}^{-1}$ for the three rate of $\mathrm{N}$ fertilizer while the controller was consistently $10 \mathrm{~kg} \mathrm{~N} \mathrm{ha}^{-1}$ lower. These high prices are due to the $\mathrm{N}$ content, as well as the higher plant mass in N120 fertilization and the higher seed yields in the same fertilization. This can also be explained by the high linear correlations between total $\mathrm{N}$ uptake and crop height $\left(\mathrm{r}=0.67^{\mathrm{*}}\right.$, Table 4.). 
NUE was affected by fertilization. According to our results, NUE decreased with the increase of nitrogen units. Expressly, the yield of soybeans in seed decreased with increasing $\mathrm{N}$ units. The results agree with Halvorson et al. (2006).

NHI was affected by tillage fertilization and year. The nitrogen harvest index of the crop was lower than the N120 fertilizer compared to the control and generally followed the opposite course. This is verified by the negative relationship with $\mathrm{N}$ uptake in upper parts $\mathrm{kg} \mathrm{ha}^{-1}\left(\mathrm{r}=-0.907^{* * 1} p<0.001\right)$. The nitrogen harvesting index is 0.8 for all operations. It is therefore noted that when the direction of production of the crop is the seed, the nitrate fertilization yields.

NAE was affected by tillage and fertilization. The factor of fertilization had a positive effect on the price of the NAE index with the price range ranging from 1.25 (N80, Year A) to 3.61 (N120, Year B). So, the higher prices of index, the higher soybean seed yields. If the cultivation of soy focusses on seed production, it will exploit as much of applied N. While NAE is only determined by seed yield, we see that there is a significant correlation with $\mathrm{N}$ uptake in Seed $\mathrm{kg} \mathrm{ha}^{-1}\left(\mathrm{r}=0.84^{* * *}\right)$.

Eff of absorption ( $\mathrm{Nt} / \mathrm{Ns}$ ) was by tillage, fertilization and tillage* fertilization. With the rising of $\mathrm{N}$ rates, the absorption of $\mathrm{N}$ from the whole plant decreased. For the first year, the difference between N80 and N120 in CT was 39\% while in NT it was 34\%. Therefore, the increase of nitrogen units was greater than the increase in $\mathrm{N}$ total uptake. There is also a small negative correlation with $\mathrm{N}$ uptake in seed $\left(\mathrm{r}=-0.3599^{\mathrm{ns}}\right)$.

Tillage, fertilization and year statistically affect Eff of uptake Gw/NT. The effects of uptake were decreased while $\mathrm{N}$ rates rise in both years. Regarding the tillage, in the first year the difference between witness and N120 in CT was $9.9 \%$ while for NT it was $7.8 \%$. In contrast to the 2 nd year, the difference between witness and N120 was higher in NT. The correlation between effects of uptake with N\% in seeds and N uptake in seed $\mathrm{kg} \mathrm{ha}^{-1}$ is negative ( $\mathrm{r}=-0.89$ and $\mathrm{r}=-0.95$ respectively) (Table 5).

The given Figure (Figure 2) illustrate that there is a linear correlation between yield $\left(\mathrm{kg} \mathrm{ha}^{-1}\right), \mathrm{N}$ uptake in seed $\left(\mathrm{kg} \mathrm{N} \mathrm{ha}^{-1}\right)$ and $\mathrm{N}$ uptake upper parts $\left(\mathrm{kg} \mathrm{N} \mathrm{ha}^{-1}\right)$. As the yield increases, the nitrogen absorption from the seeds and the aboveground part of the plant also increases $\left(R^{2}=0.923\right)$. This result is important if we consider that soybean cultivation is aimed at animal feed and seeds

Table 4. Linear Correlation ( $r$-values) matrix between soil \& plant properties.

\begin{tabular}{|c|c|c|c|c|c|c|c|c|c|c|c|c|}
\hline & $\begin{array}{l}\text { DM yield } \\
\text { upper parts } \\
\text { STOVER } \\
\left(\mathrm{kg} \mathrm{ha}^{-1}\right)\end{array}$ & $\begin{array}{c}\mathrm{N} \text { in } \\
\text { upper } \\
\text { parts } \\
(\%)\end{array}$ & $\begin{array}{c}\text { Yield } \\
\left(\mathrm{kg} \mathrm{ha}^{-1}\right)\end{array}$ & $\begin{array}{c}\mathrm{N} \text { in seeds } \\
(\%)\end{array}$ & $\begin{array}{c}\mathrm{N} \text { uptake in } \\
\text { upper parts } \\
\left(\mathrm{kg} \mathrm{ha}^{-1}\right)\end{array}$ & $\begin{array}{c}\mathrm{N} \text { uptake in } \\
\text { SEED } \\
\left(\mathrm{kg} \mathrm{ha}^{-1}\right)\end{array}$ & $\begin{array}{c}\mathrm{N} \text { total } \\
\text { uptake } \\
\left(\mathrm{kg} \mathrm{ha}^{-1}\right)\end{array}$ & NUE & NHI & NAE & $\begin{array}{c}\text { Effect of } \\
\text { absorption } \\
\left(\mathrm{Nt} \cdot \mathrm{Ns}^{-1}\right)\end{array}$ & $\begin{array}{c}\text { Effect of } \\
\text { uptake } \\
\left(\mathrm{GwNt}^{-1}\right)\end{array}$ \\
\hline Total soil porosity (\%) & $.618^{\cdots}$ & $.492^{\prime \prime}$ & $.591^{\cdots}$ & $.4865^{\prime \prime}$ & $.582^{\cdots}$ & $.585^{\cdots}$ & $.608^{\prime \prime}$ & $-.127 \mathrm{~ns}$ & $-.461^{*}$ & $.403 n s$ & $.096^{\mathrm{ns}}$ & $-.603^{\cdots}$ \\
\hline $\begin{array}{c}\text { Penetration resistance } \\
0-30 \mathrm{~cm},(\mathrm{MPa})\end{array}$ & $-.569^{\cdots}$ & $-.495^{\prime \prime}$ & $-.561^{\cdots}$ & $-.501^{*}$ & $-.571^{\cdots}$ & $-.577^{\cdots}$ & $-.599^{\cdots}$ & $.023 \mathrm{~ns}$ & $.446 \mathrm{~ns}$ & $-.356 \mathrm{~ns}$ & $-.250^{\mathrm{ns}}$ & $-.601^{\cdots}$ \\
\hline Organic matter \% & $.627^{* \prime}$ & $.552 \cdots$ & $.634^{*}$ & $.563^{\cdots}$ & $.634^{\prime \prime}$ & $.652^{\cdots *}$ & $.673^{\cdots}$ & $-.125 \mathrm{~ns}$ & $-.486^{*}$ & $.442 \mathrm{~ns}$ & $.148^{\mathrm{ns}}$ & $-.670^{\cdots}$ \\
\hline $\begin{array}{l}\text { Root density } \\
\left(\mathrm{cm} 100 \mathrm{~cm}^{-3}\right)\end{array}$ & $.751^{\cdots}$ & $.529^{\cdots}$ & $.726^{\prime \prime}$ & $.720^{\cdots}$ & $.659^{\cdots}$ & $.780^{\cdots}$ & $.770^{\cdots}$ & $-.207 \mathrm{~ns}$ & $-.432 \mathrm{~ns}$ & $.598^{* * *}$ & $-.235^{\mathrm{ns}}$ & $-.774 \cdots$ \\
\hline $\begin{array}{l}\text { No nodules } \\
\left(\mathrm{cm} 100 \mathrm{~cm}^{-3}\right)\end{array}$ & $.772 \cdots$ & $.325^{\mathrm{ns}}$ & $.671^{\cdots}$ & $.648^{\cdots}$ & $.513^{\cdots}$ & $.713^{\cdots}$ & $.672^{\cdots}$ & $-.229 \mathrm{~ns}$ & $-.261 \mathrm{~ns}$ & $.619^{* * *}$ & $-.344^{\circ}$ & $-.638^{\cdots}$ \\
\hline LAI & $.826^{\prime \prime}$ & $.484^{\prime \prime}$ & $.754^{\cdots}$ & $.661^{\cdots}$ & $.652^{\cdots}$ & $.771^{* *}$ & $.761^{\prime \prime}$ & $-.244 n s$ & $-.426 \mathrm{~ns}$ & $.627^{* * *}$ & -.416 & $-.721^{\cdots}$ \\
\hline height $(\mathrm{cm})$ & $.793^{\prime \prime}$ & $.265^{\mathrm{ns}}$ & $.651^{* \prime}$ & $.805^{\prime \prime}$ & $.474^{\prime \prime}$ & $.774^{\prime \prime}$ & $.670^{\cdots \prime}$ & $-.387 \mathrm{~ns}$ & $-.156 \mathrm{~ns}$ & $.719^{* * *}$ & $-.548^{\cdots}$ & $-.718^{* \prime}$ \\
\hline No pods (plant ${ }^{-1}$ ) & $.818^{\cdots}$ & $.781^{\cdots}$ & $.868^{\cdots}$ & $.616^{\prime \prime}$ & $.875^{\cdots}$ & $.821^{\cdots}$ & $.875^{\cdots}$ & $-.034 \mathrm{~ns}$ & $\begin{array}{c}- \\
.728^{* * *}\end{array}$ & $.590^{* * *}$ & $-.256^{\mathrm{ns}}$ & $-.818^{\cdots}$ \\
\hline 1000 seed weight $(\mathrm{g})$ & $.771^{\cdots}$ & $.322^{\mathrm{ns}}$ & $.659^{* *}$ & $.695^{\cdots}$ & $.511^{\cdots}$ & $.729 \cdots$ & $.682^{\cdots}$ & $-.470^{*}$ & $-.243 n s$ & $.659^{* * *}$ & -.406 & $-.668^{\cdots *}$ \\
\hline
\end{tabular}

Significance levels: ${ }^{*} \mathrm{p}<0.05 ;{ }^{* *} \mathrm{p}<0.01 ;{ }^{* * *} \mathrm{p}<0.001 ;$ ns, not significant $(\mathrm{p}>0.05)$ 
Kakabouki I et al. (2020). Not Bot Horti Agrobo 48(2):799-813

Table 5. Linear correlation ( $r$-values) between $\mathrm{N}$ indices

\begin{tabular}{|c|c|c|c|c|c|}
\hline & NUE & NHI & NAE & $\begin{array}{c}\text { Effective of } \\
\text { absorption } \\
\left(\mathrm{Nt} \mathrm{Ns}^{-1}\right)\end{array}$ & 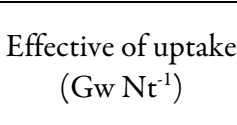 \\
\hline $\begin{array}{c}\mathrm{N} \text { in upper parts } \\
(\%)\end{array}$ & $.047^{\mathrm{ns}}$ & $-.932^{* * *}$ & $.486^{\circ}$ & $-.125^{\mathrm{ns}}$ & $-.780^{* * * *}$ \\
\hline $\begin{array}{c}\mathrm{N} \text { in seeds } \\
(\%)\end{array}$ & $-.192^{\mathrm{ns}}$ & $-.215^{\mathrm{ns}}$ & $.681^{* * *}$ & $-.261^{\mathrm{ns}}$ & $-.987^{* * *}$ \\
\hline $\begin{array}{l}\mathrm{N} \text { uptake in upper } \\
\text { parts }\left(\mathrm{kg} \mathrm{ha}^{-1}\right)\end{array}$ & $-.042^{\mathrm{ns}}$ & $-.908^{* * *}$ & $.632^{* * *}$ & $-.255^{\mathrm{ns}}$ & $-.873^{* * *}$ \\
\hline $\begin{array}{l}\text { N uptake in SEED } \\
\qquad\left(\mathrm{kg} \mathrm{ha}^{-1}\right)\end{array}$ & $-.170^{\mathrm{ns}}$ & $-.513^{* * *}$ & $.838^{* * *}$ & -.356 & $-.956^{*}$ \\
\hline $\begin{array}{l}\mathrm{N} \text { total uptake } \\
\left(\mathrm{kg} \mathrm{ha}^{-1}\right)\end{array}$ & $-.132^{\mathrm{ns}}$ & $-.675^{* * *}$ & $.800^{* * *}$ & $-.338^{*}$ & $-.967^{* *}$ \\
\hline
\end{tabular}

Nitrogen indicators are used to help us understand if the nitrogen applied is used by plants or lost. Nitrogen Used Efficiency, express the ability of plants to use nitrogen effectively. More specifically, the higher this index, the better the plant uses nitrogen. In the present experiment in the application of $80 \mathrm{~kg} \mathrm{n}$ per hectare, it seems to be the best dose of nitrogen. Garrido and López-Bellido (2001), reported that whether the indicator 's value, is higher than 1, then the plants get the excess nitrogen and can be used for crop phytoremediation.

Nitrogen harvest index express how much of the applied nitrogen is contained in the seed, compared to the nitrogen content of the plant. This indicator informs us which is the most important part of the plant, in terms of nitrogen accumulation. In this study was observed that the control and immediately after the lower nitrogen dose (N80) had the higher NHI. This means that excess nitrogen was used to grow the plants and not the seeds. This can be useful for crops used to feed animals as a silage.

Nitrogen agronomic efficiency refers to the effects of the amount of nitrogen on seed yield. Thus, this indicator in the present study was positive correlated with the nitrogen amount that is to the $120 \mathrm{~kg}$ nitrogen per hectare. So, the higher this indication, the higher the yield of the seeds.

However, the effects of absorption show how much of the nitrogen fertilizer is absorbed by the plant. This indicator is negatively related to the dose of nitrogen. This informs us that the best amount the plant can get is $80 \mathrm{~kg} \mathrm{ha}^{-1}$. In addition, the Effects of uptake express how total nitrogen uptake is related to yield. Our results show that the plants did not use the uptake nitrogen to increase the yield but for other reasons, such as to increase their height. Through the indicators, it is therefore understandable that soybean uses the nitrogen derived from the $\mathrm{N}_{2}$ fixation and the organic matter to increase the yield and not the nitrogen applied. This is why the control had the highest value in effects of nitrogen uptake. Therefore, nitrogen indicators can efficiently express the soybean fertilization in two different tillage systems.

\section{Conclusions}

In conclusion, different doses of nitrogen had different effects on plant characteristics, for example at plant height, and on soil properties such as organic matter and the number of nodules. In addition, it has been observed that no tillage has a positive effect on soil properties more than agronomic characteristics. However, it is well known that the condition of the soil indirectly effects on soybean growth. The role of indicators is to show whether each dose of nitrogen has a significant effect on plant growth or whether its effects are not beneficial to plants and soil properties. Due to the factors on which they depend, such as the N\% and N uptake in upper parts, they seem to be to be affected by both different doses of nitrogen and tillage systems. However, 
at high amounts of nitrogen, while the nitrogen content is increased, the indicators decrease, which means that the excess nitrogen does not have essential effects on plant growth. Hence, nitrogen indicators can express the fertilization in soybean cultivation in two different tillage systems.

\section{Conflict of Interests}

The authors declare that there are no conflicts of interest related to this article.

\section{References}

Alvarez R, Steinbach HS (2009). A review of the effects of tillage systems on some soil physical properties, water content, nitrate availability and crops yield in Argentine Pampas. Soil and Tillage Research 104:1-15.

Attia A, Shapiro C, Kranz W, Mamo M, Mainz M (2015). Improved yield and nitrogen use efficiency of corn following soybean in irrigated sandy loams. Soil Science Society of America Journal 79(6):1693-1703.

Bairwa HL, Mahawer LN, Shukla AK, Kaushik RA, Mathur SR (2009). Response of integrated nutrient management on growth, yield and quality of okra (Abelmoschus esculentus). Indian Journal of Agricultural Sciences 79(5):381-384.

Bergersen FJ (1958). The bacterial component of soybean root nodules; changes in respiratory activity, cell dry weight and nucleic acid content with increasing nodule age. Microbiology 19(2):312-323.

Bilalis D, Karkanis A, Patsiali S, Agriogianni M, Konstantas A, Triantafyllidis V (2011). Performance of wheat varieties (Triticum aestivum $\mathrm{L}$.) under conservation tillage practices in organic agriculture. Notulae Botanicae Horti Agrobotanici Cluj-Napoca 39(2):28-33

Bilalis DJ, Karkanis A, Papastylianou P, Patsiali S, Athanasopoulou M, Barla G, Kakabouki I (2010). Response of organic linseed (Linum usitatissimum L.) to the combination of tillage systems, (minimum, conventional and no-tillage) and fertilization practices. Seed and oil yield production. Australian Journal of Crop Science 4:700-705.

Bremner JM (1960). Determination of nitrogen in soil by Kjedahl method. Journal of Agricultural Science $\quad$ 55:11-33

Crookston RK, Kurle JE, Copeland PJ, Ford JH, Lueschen WE (1991). Rotational cropping sequence affects yield of corn and soybean. Agronomy Journal 83(1):108-113.

Elmore RW (1990). Soybean cultivar response to tillage systems and planting date. Agronomy Journal 82(1):69-73.

Ferreira MC, Andrade DDS, Chueire LMDO, Takemura SM, Hungria M (2000). Tillage method and crop rotation effects on the population sizes and diversity of bradyrhizobia nodulating soybean. Soil Biology and Biochemistry 32(5):627-637.

Gai Z, Zhang J, Li C (2017). Effects of starter nitrogen fertilizer on soybean root activity, leaf photosynthesis and grain yield. Plos One 12:1-15.

Goss MJ, De Varennes A (2002). Soil disturbance reduces the efficacy of mycorrhizal associations for early soybean growth and $\mathrm{N}_{2}$ fixation. Soil Biology and Biochemistry 34(8):1167-1173.

Halvorson AD, Reule CA (2006). Irrigated corn and soybean response to nitrogen under no-till in northern Colorado. Agronomy Journal 98(5):1367-1374.

Hao QN, Zhou XA, Ai HS, Wang C, Zhou R, Chen SL (2011). Identification of genes associated with nitrogen-use efficiency by genome-wide transcriptional analysis of two soybean genotypes. BMC Genomics 12(1):525.

Hardy RWF, Havelka UD (1975). Nitrogen fixation research: a key to world food? In: Abelson PH (Eds.), Food, Politics, Economics, Nutrition and Research. American Association for the Advancement of Science. Washington, DC 188(4188):633-643.

Hellal FA, Abdelhamid MT (2013). Nutrient management practices for enhancing soybean (Glycine max L.) production. Acta Biológica Colombiana 18(2):239-250.

Jadhav AS, Andhale RP, Patil PA (2009) Effect of integrated nutrient management on yield attributes and yield of soybean. Journal Maharashtra Agricultural University 34:86-88.

Kakabouki IP, Hela D, Roussis I, Papastylianou P, Sestras AF, Bilalis D (2018). Influence of fertilization and soil tillage on nitrogen uptake and utilization efficiency of quinoa crop (Chenopodium quinoa Willd.) Journal of Soil Science and Plant Nutrition 18(1):220-235. 
Keyser HH, Li F (1992). Potential for increasing biological nitrogen fixation in soybean. In Biological Nitrogen Fixation for Sustainable Agriculture. Springer, Dordrecht pp 119-135

Kihara J, Martius C, Bationo A, Vlek PL (2011). Effects of tillage and crop residue application on soybean nitrogen fixation in a tropical ferralsol. Agriculture 1(1):22-37.

Kokko EG, Volkmar KM, Gowen B, Entz T (1993). Determination of total root surface area in soil core samples by image analysis. Soil and Tillage Research 26:33-43. DOI: 10.1016/0167-1987(93)90084-3

Kumawat SM, Dhakar LL, Maliwal PL (2000). Effect of irrigation regimes and nitrogen on yield, oil content and nutrient uptake of soybean (Glycine max (L.) Merrill). Indian Journal Agronomy 45:361-366.

Lueschen WE, Ford JH, Evans SD, Kanne BK, Hoverstad TR, Randall GW, Hicks DR (1992). Tillage, row spacing, and planting date effects on soybean following corn or wheat. Journal of Production Agriculture 5(2):254-260.

Martre P, Porter JR, Jamieson PD, Triboï E (2003). Modeling grain nitrogen accumulation and protein composition to understand the sink/source regulations of nitrogen remobilization for wheat. Plant Physiology 133(4):1959-1967.

Mere V, Singh AK, Singh M, Jamir Z, Gupta RC (2013). Effect of nutritional schedule on productivity and quality of soybean varieties and soil fertility. Legume Research-An International Journal 36(6):528-534.

Naik K R., Rao SK (2004). Effect of nitrogen application at reproductive phase on seed production of soybean. Seed Research 32:94-95.

Ntambo MS, Chilinda IS, Taruvinga A, Hafeez S, Anwar T, Sharif R, Chambi C, Kies ～L (2017). The effect of rhizobium inoculation with nitrogen fertilizer on growth and yield of soybeans (Glycine max L). International Journal of Biosciences 10:163-172.

Okoth JO, Mungai NW, Ouma JP, Baijukya FP (2014). Effect of tillage on biological nitrogen fixation and yield of soybean (Glycine max L. Merril) varieties. Australian Journal of Crop Science 8(8):1140.

Osborne SL, Riedell WE (2006). Starter nitrogen fertilizer impact on soybean yield and quality in the northern Great Plains. Agronomy Journal 98(6):1569-1574.

Pradhan L, Rout D, Mohapatra BK (1995). Response of soybean (Glycine max) to nitrogen and phosphorus. Indian Journal Agronomy 40:305-306.

Rafael J, López-Bellido Garrido, Luis López-Bellido (2001). Effects of crop rotation and nitrogen fertilization on soil nitrate and wheat yield under rainfed Mediterranean conditions. Agronomie 21(6-7):509-516. DOI: 10.1051/agro:2001140

Salvagiotti F, Cassman KG, Specht JE, Walters DT, Weiss A, Dobermann A (2008). Nitrogen uptake, fixation and response to fertilizer N in soybeans: A review. Field Crops Research 108(1):1-13.

Sanginga N, Dashiell KE, Diels J, Vanlauwe B, Lyasse O, Carsky RJ, ... Rodomiro O (2003). Sustainable resource management coupled to resilient germplasm to provide new intensive cereal-grain-legume-livestock systems in the dry savanna. Agriculture, Ecosystems \& Environment 100(2-3):305-314.

Saxena SC, Chandal AS (1992). Effect of nitrogen fertilization on different varieties of soybean. Indian Journal Agriculture Science 62:695-697.

Schipanski ME, Drinkwater LE, Russelle MP (2010). Understanding the variability in soybean nitrogen fixation across agroecosystems. Plant and Soil 329(1-2):379-397.

Seneviratne G, Van Holm LHJ, Ekanayake EMHGS (2000). Agronomic benefits of rhizobial inoculant use over nitrogen fertilizer application in tropical soybean. Field Crops Research 68(3):199-203.

Sidiras N, Avgoulas C, Bilalis D, Tsougrianis N (1999). Effect of tillage and fertilization on biomass, roots, N accumulation and nodule bacteria of vetch (Vicia sativa cv. Alexander). Journal of Agronomy and Crop Science 182:209-216.

Skoulou V, Mariolis N, Zanakis G, Zabaniotou A (2011). Sustainable management of energy crops for integrated biofuels and green energy production in Greece. Renewable and Sustainable Energy reviews 15(4):1928-1936.

Souza R., Teixeira I, Reis E, Silva A (2016). Soybean morpho-physiology and yield response to seeding systems and plant populations. Chilean Journal of Agricultural Research 76(1):3-8.

Sprent JI (1985). Nitrogen fixation in arid environments. In: GE Wickens, JR Goodin and DV Field (Eds). Plants for Arid Lands. George Allen and Unwin. London. pp 215-229.

Streeter J (1988). Inhibition of legume nodule formation and $\mathrm{N}_{2}$ fixation by nitrate. Critical Reviews in Plant Sciences 7:1-23.

Vitousek PM, Hattenschwiler S, Olander L, Allison S (2002). Nitrogen and nature. Ambio: Am Journal of the Human Environment 31:97-101. 
Walkey A, Black IA (1934). An examination of the Degtiareff methods for determining soil organic and proposed modification of chromic acid titration method. Soil Science 37:29-38.

Wang SQ, Han XZ, Qiao YF, Yan J, Li XH (2009). Nodule growth, nodulation and nitrogen fixation in soybean (Glycine max L.) as affected by nitrogen application [J]. Acta Agriculturae Boreali-Sinica 2.

Werner D, Newton WE (2005). Nitrogen fixation in agriculture, forestry, ecology and environment. Springer, Netherlands. Wesley TL, Lamond RE, Martin VL, Duncan SR (1998). Effects of late-season nitrogen fertilizer on irrigated soybean yield and composition. Journal of Production Agriculture 11:331-336.
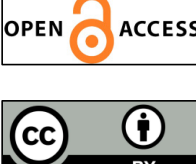

The journal offers free, immediate, and unrestricted access to peer-reviewed research and scholarly work. Users are allowed to read, download, copy, distribute, print, search, or link to the full texts of the articles, or use them for any other lawful purpose, without asking prior permission from the publisher or the author.

License - Articles published in Notulae Botanicae Horti Agrobotanici Cluj-Napoca are Open-Access, distributed under the terms and conditions of the Creative Commons Attribution (CC BY 4.0) License.

(c) Articles by the authors; UASVM, Cluj-Napoca, Romania. The journal allows the author(s) to hold the copyright/to retain publishing rights without restriction. 